\title{
STRATEGI BRANDING KOTA WISATA BATU (KWB) MELALUI MEDIA INTERNAL DAN EKSTERNAL HUBUNGAN MASYARAKAT (HUMAS) PEMERINTAH KOTA BATU
}

\author{
Melianus Deni Bau ${ }^{1} \&$ Herru Prasetya Widodo ${ }^{2}$ \\ ${ }^{1,2}$ Program Studi Ilmu Komunikasi, Universitas Tribhuwana Tunggadewi \\ Email korespondensi : denibau07@gmail.com
}

\begin{abstract}
Batu City is one of the well known tourist cities in Indonesia. With so many tourist destinations that are so many and interesting that make Batu City want to introduce to the world about the uniqueness of its brand Batu Tourism City $(K W B)$. The purpose of this study was to determine the use of internal and external media of the City Government Public Relations of Batu in maintaining the branding of Batu Tourism City (KWB). This research was conducted in Batu City Public Relations and the type of research used was descriptive qualitative. Sources of data in this study are primary data and secondary data. Data collection techniques used in this study were interviews, documentation, observation. Researchers analyze the data obtained in the field with three stages carried out for processing with data analysis in the form of data analysis, data presentation and drawing conclusions. Forms of Batu Tourism City branding strategy through media carried out by Batu City Government Public Relations by utilizing internal and external media in maintaining Batu City branding as Batu Tourism City, there are three points namely brand positioning where Batu City defines Agro Tourism excellence as a distinctive feature of Batu City, the Identy brand that conducted to convey brand intentions through promoting tourism, publicizing Kota Batu activities and providing online-based services, brand personality through conducting comparative studies and community participation in the form of word of mouth.
\end{abstract}

Keywords: Branding Strategy, Internal and External Media, Batu Tourism City.

\begin{abstract}
Abstrak: Kota Batu merupakan salah satu kota wisata yang cukup dikenal di indonesia. Dengan banyaknya destinasi wisata yang begitu banyak dan menarik sehingga membuat Kota batu ingin memperkenalkan kepada dunia tentang keunikan yang ada dengan brand-nya Kota Wisata Batu (KWB). Tujuan dari penelitian ini adalah untuk mengetahui media internal dan eksternal Humas Pemerintah Kota batu dan juga strategi branding Kota Wisata Batu (KWB). Penelitian ini dilakukan di Humas Pemerintah Kota Batu dan Jenis penelitian yang digunakan adalah deskriptif kualitatif. Sumber data dalam penelitian ini adalah data primer dan juga data sekunder. Teknik pengumpulan data yang digunakan dalam penelitian ini adalah wawancara, dokumentasi, observasi. Peneliti menganalisa data yang didapatkan dilapangan dengan tiga tahap yang dilakukan untuk diolah dengan analisis data berupa analisa data, penyajian data dan penarikan kesimpulan. Media Internal yang dimiliki Humas pemerintah Kota Batu seperti Majalah Panderma, Buletin Kaleodskop dan juga Televisi. Kemudia Media eksternalnya berupa website, ATV dan juga media sosialnya. Bentuk Strategi branding Kota Wisata Batu melalui media yang dilakukan Humas Pemerintah Kota Batu dengan memanfaatkan media internal dan eksternal dalam menjaga branding Kota batu sebagai Kota Wisata Batu terdapat tiga poin yaitu brand positioning dimana Kota Batu medefinisikan keunggulan Agrowisata sebagai ciri khas Kota Batu, brand Identy yang dilakukan untuk menyampaikan maksud merek melalui mempromosikan wisata, mempublikasikan kegiatan Kota Batu dan memberkan pelayanan berbasis online, brand personality melalui mengadakan studi banding dan pertisipasi masyarakat berupa word of mouth.
\end{abstract}

Kata Kunci: Strategi branding, Media Internal dan Eksternal, Kota Wisata Batu.

\section{Pendahuluan}

Komunikasi memiliki peran yang sangat penting dalam kegiatan public relations. Hal ini terjadi karena dalam menyampaikan informasi public relations perlu melakukan komunikasi, yang berarti penyampaian pesan kepada publik. Public relations merupakan elemen penghubung antara perusahaan dan stakeholders. 
Menurut (Jefkins, 2004) public relations didefinisikan sebagai komunikasi yang dilakukan secara terencana. Komunikasi yang dilakukan public relations ditujukan untuk publik, di luar maupun di dalam suatu lembaga. Oleh sebab itu, tujuan komunikasi yang dilakukan public relations adalah untuk mencapai suatu pengertian demi pengembangan suatu perusahaan.

Ketatnya persaingan brand antara suatu daerah dengan daerah yang lainnya terutama di dalam hal pariwisata menyebabkan masing-masing daerah harus pintar dan tepat dalam menentukan dan menerapkan strategi pengelolaan brand. Hal ini perlu menjadi perhatian serius karena brand dapat menarik keuntungan secara materi maupun nonmateri yang baik (Fajrini, Bakti, dan Novianti, 2018). Pentingnya branding dalan Mursyid (2016) sebagai ciri khas untuk memudahkan konsumen membedakan antara produsen satu dengan yang lainnya, kini mulai berkembang di segala bidang. Strategi branding menurut Schultz dan Barnes adalah manjemen suatu merek yang kegiatannya ditujukan untuk mengorganisasi semua aspek yang tujuannya adalah untuk menciptakan suatu brand (Hermawan, 2016). Dalam membangun branding, strategi yang bisa dilakukan adalah dengan memilih media untuk mempromosikan produk perusahaan (Oktaviani, 2018).

Sebagaimana sebuah perusahan, sebuah kota juga menerapkan strategi pengelolaan brand, salah satunya adalah Kota Batu. Pada tahun 2019 Kota Batu mendapatkan penghargaan sebagai destinasi wisata halal unggulan oleh Indonesia Muslim Travel Index (IMTI) yang langsung diserahkan oleh Menteri Pariwisata RI Arief Yahyadi kepada Pemerintah Batu.

Dalam menjaga branding nama Kota Wisata Batu (KWB) dibutuhkan orang yang profesional di bidangnya, maka dari itu peran seorang Humas sangat dibutuhkan disuatu lembaga atau instansi milik Pemerintah yang merupakan suatu keharusan fungsional dan operasional dalam upaya menyebarluaskan informasi atau untuk mempublikasikan kegiatan dan aktivitas instansi bersangkutan kepada masyarakat. Public relations adalah fungsi manajemen yang khas dalam mendukung pembinaan dan memelihara jalur bersama antara organisasi dengan publiknya melalui komunikasi, pengertian, penerimaan dan kerjasama yang melibatkan semua aspek dalam organisasi menjadi tahu mengenai respon dari opini publik. Membuat penetapan dan membebankan tanggungjawab organisasi untuk melayani kepentingan publik serta mendukung organisasi dalam mengikuti dan dan memanfaatkan perubahaan secara efektif dalam bertindak sebagai bentuk peringatan awal dalam membantu mengurangi ketidakpastian dan menggunakan penelitian sebagai sarana utama dalam melakukan komunikasi yang sehat (Ruslan, 2014).

\section{Metode Penelitian}

Metode penelitian yang digunakan dalam penelitian ini adalah kualitatif deskriptif. Penelitian jenis ini menekankan pada esensi atau makna ketimbang generalisasi (Sugiyono, 2014). Penelitian dilakukan di Humas Pemerintah Kota Batu. Data dikumpulkan dengan 3 teknik, yaitu observasi, wawancara, dan dokumentasi.

Data yang sudah dikumpulkan kemudian dianalisasi menggunakan tiga komponen (Zuriah, 2007). Pertama, Reduksi data yaitu laporan lapangan dalam bentuk uraian yang akan direduksi, dipilah hal-hal yang pokok, dan fokus pada hal yang penting serta membuang hal yang tidak penting serta membuang hal yang tidak diperlukan. Kedua, penyajian data (data display), penyajian data dalam bentuk ini berupa tabel dan teks yang bersifat naratif merupakan penjelasan agar mempunyai makna yang dapat di pahami oleh orang lain. Ketiga, penarikan kesimpulan (verifikasi), akhir dari hasil penelitian ini adalah membuat kesimpulan/verifikasi. 
JISIP: Jurnal Ilmu Sosial dan Ilmu Politik

ISSN. 2442-6962

Vol. 9. No. 2 (2020)

\section{Hasil dan Pembahasan}

\section{Media Internal dan Eksternal Humas Pemerintah Kota Batu dalam Menjaga Branding Kota Wisata Batu (KWB).}

Hubungan masyarakat atau sering dikenal dengan istilah Humas merupakan suatu hal yang sangat penting dan dibutuhkan oleh suatu lembaga maupun instansi. Begitupun dengan Kota Batu dalam melakukan tugas dan aktivitas khusu snya dalam menjaga branding sebagai Kota wisata Batu (KWB). City branding adalah usaha membangun suatu pembedaan dan mengkomunikasikan dan memperkokoh jati diri sebuah kota sehingga mudah dikenali (Lestari, 2016; Christin \& Fauzan, 2015; Jannah, arifin dan Kusumati, 2014). Untuk melakukan perlu menggunakan media berkaitan dengan bagaimana melalui media kita dapat mendemonstrasikan keunggulan dari Kota yang menjadikan ciri khas untuk bersaing dengan Kota Kota yang lain. Media yang digunakan oleh hubungan masyarakat (Humas) Pemerintah Kota Batu adalah media internal dan media eksternal.

\section{1) Media Internal}

\section{a. Media cetak}

Media cetak merupakan segala barang cetak yang dipergunakan sebagai sarana penyampaian. Media cetak yang dimiliki oleh Humas Pemerintah Kota Batu yaitu berupa majalah dan buletin.
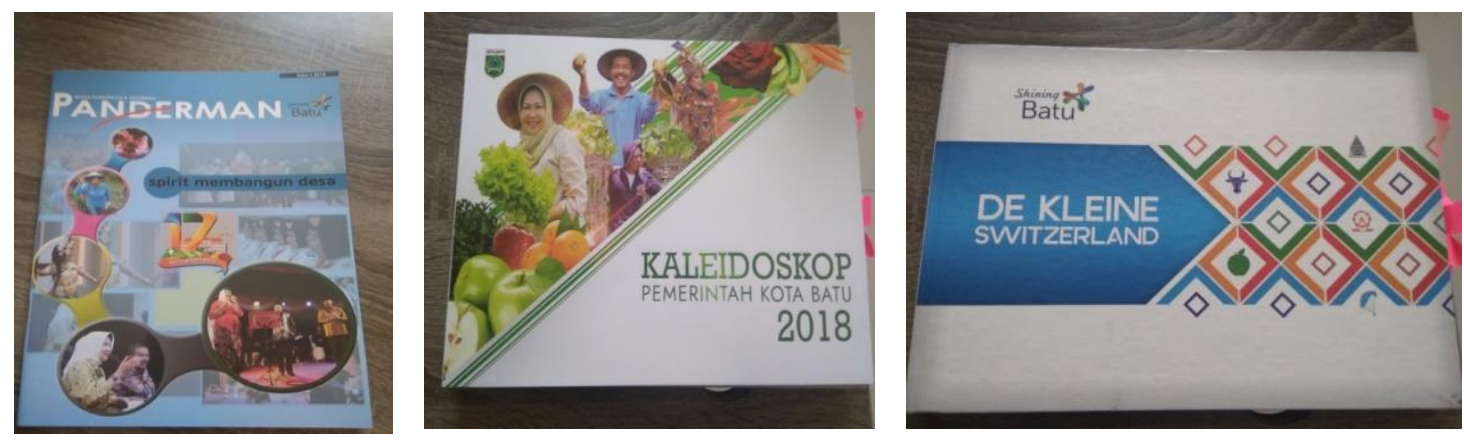

Gambar 1. Media cetak yang diterbitkan internal Humas Kota Batu

Sumber : Dokumen peneliti

Pada ketiga buku diatas yang pertama dan kedua Panderman dan Kaleidoskop berisi berbagai macam kegiatan baik itu kegiatan Walikota Maupun Wakil Walikota yang dilengkapi fotofoto. Kemudian pada Buku yang ketiga De Kleine berisi profil pemerintah Kota Batu baik itu dari lembaga pemerintaham sendiri hingga segala bentuk tempat wisata yang ada dalam Kota Batu sendiri.

\section{b. Media Elektronik}

Media internal elektronik yang digunakan oleh Humas Pemerintah Kota Batu Adalah televisi sebagai media informasi untuk setiap kegiata agenda maupun berupa himbauan kepada semua pihak internal dapat melalui Televisi yang ada di setiap dinas pemerintahan yang ada dalam gedung Among Tani.

\section{2) Media Eksternal}

Media eksternal merupakan media-media yang dimiliki oleh pemerintah Kota Batu dan dapat membantu dalam mempublikasikan ke masyarakat maupun publik luar. Selain itu juga media eksternal juga lebih kepada media luar yang menjalin kerjasama dengan hubungan masyarakat (Humas) Pemerintah Kota Batu dalam membantu meliput serta mempublikasikan kegiatankegiatan Kota Batu. Media ektsernal Humas Pemerintah Kota Batu terbagi dalam 3 bagian yaitu media elektronik, media online dan juga media sosial. Untuk media luar yang menjadi mitra kerja 
dengan Humas Pemerintah Kota Batu dalam menjalin kerjasama yang ada antara Humas Pemerintah Kota Batu dengan media-media luar ini tidaklah tetap dan resmi seperti dengan menggunakan MOU, melainkan hubungan yang dijalin berupa sistem by order dimana yang dimaksudkan adalah apabila dari media-media ini ingin meliput tentang Kota batu maka akan dikomunikasikan dan dikonfirmasikan lewat Humas Pemerintah Kota Batu. Begitupun demikian dari Humas Pemerintah Kota Batu ingin mempublikasikan informasi yang ada maka akan menghubungi pihak dari media-media yang ada. Namun media yang menjalin kerjasama dengan Humas Pemerintah Kota Batu walaupun tanpa menggunakan MOU namun dari Humas Pemerintah Kota Batu memiliki kriteria-kriteria tertentu dalam menjalin kerjasama sebagai contoh mediamedia ini harus jelas secara organisasinya, selalu meliput kegiatan Pemerintah Kota Batu

\section{a. Media Online}

Media Online yang dimiliki oleh Humas Pemerintah Kota Batu yaitu Websitenya (humas.batukota.go.id). dalam website Humas pemerintah Kota Batu ini juga terdapat beritaberita, foto, video maupun E-Book serta terdapat mading digital.

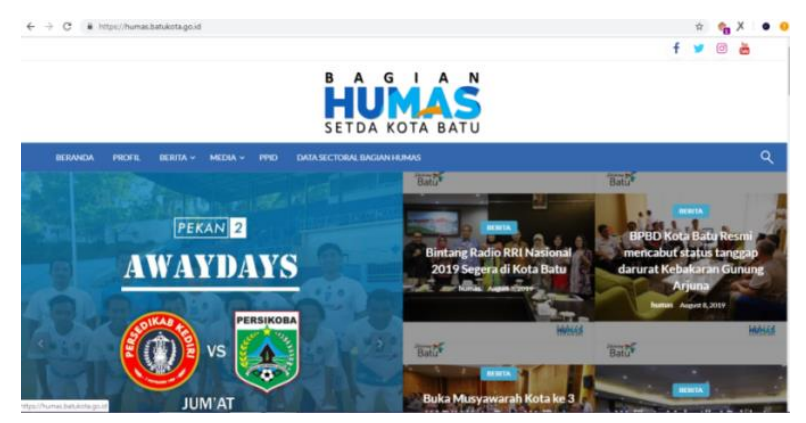

Gambar 2. Website Humas Pemerintah Kota Batu

\section{b. Media Elektronik}

Media internal elektronik yang digunakan oleh Humas Pemerintah Kota Batu Adalah televisi. Televisi yang menjadi salah satu media internal Humas Pemerintah Kota Batu adalah ATV. ATV ini biasa digunakan dalam membantu memberikan informasi tentang keadaan kota batu kepada seluruh masyarakat kota Batu.

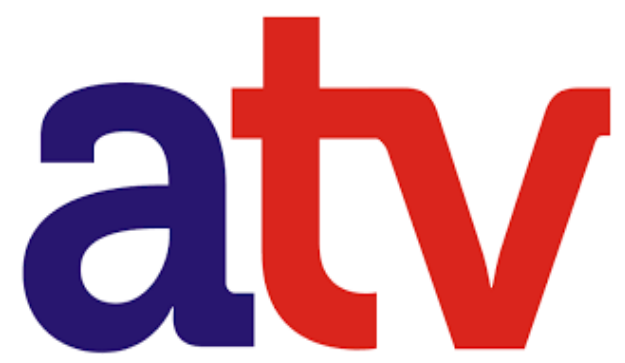

Gambar 3. Media elektronik yang dimiliki Pemerintah Kota Batu

\section{c. Media Sosial}

Media sosial yang dimiliki Humas Pemerintah Kota Batu seperi facebook (Panderman KWB), instagram (@humas_pemkotbatu), youtube (Humas Pemerintah Kota Batu), twitter (@humasKotabatu)@mail (humas.Kotabatu@gmail.com).

\section{Gambar.11 Media Sosial Humas Pemerintah Kota Batu}


Kemudian untuk media luar yang menjadi mitra kerja Humas pemerintah Kota Bantu yang dimana media-media luar yang menjadi rekan dan sudah menjalin kerjasama dengan Pemerintah Kota Batu yaitu seperti media cetak harian maupun mingguan, media cetak harian berupa seperti kompas, jawa pos, radar Batu, malang post dan media cetak lainnya kemudian untuk media cetak mingguan seperti Jatim Post, Malang News, Radar Bangsa. Lalu untuk media online eksternalya seperti times indonesia, malang voice, memomo online dan yang lainnya kemudian media elektronik yang terdiri dari dua (2) yaitu televisi seperti NET TV, Metro TV, JTV, Arema TV dll, dan yang terakhir adalah radio yang meliputi Radio Tidar Sakti dan radio city guide.

\section{Strategi Branding Kota Wisata Batu (KWB) Melalui Media Internal dan Eksternal Humas Pemerintah Kota Batu.}

Dalam menjaga branding Kota Batu sebagai Kota Wisata Batu atau yang sering dikenal dengan istilah (KWB) media menjadi prioritas penting. Maka pihak Pemerintah Kota Batu khususnya Humas menggunakan media media yang ada yaitu media internal maupun media ekternal yang ada untuk membantu menjaga branding Kota Batu yang ada. Dalam menjaga branding yang ada dengan menggunakan media internal dan media eksternal tidaklah ada strategi khusus yang diterapkan oleh Humas Pemerintah Kota Batu. Namun yang pasti, pemerintah selalu mempubikasikan segala bentuk kegiatan kepala daerah maupun wakil kepala daerah serta kegiatan Pemerintah baik itu dari setiap dinas yang ada dan juga dan dan mempromosikan segala destinasi wisata yang baru.

\section{a) Brand Positioning Melalui Media Internal dan eksternal Humas Pemerintah Kota Batu.}

Dalam hal ini Humas Pemerintah Kota Batu melakukan brand positioning dengan menggunakan media yang ada baik itu media internal maupun media eksternal. Dalam mengidentifikasikan keunggulan ini Kota Batu memiliki keunggulan dalam segi wisata dalam hal ini keunggulan wisata berupa agrowisata yaitu wisata-wisata yang berbasis pertanian seperti contoh wisata Petik Apel, Wisata Kebun Jeruk, Pujon Kidul dan lainnya. Kemudian ada juga Wisata Modern seperti contohnya Museum angkot, Jatim Park dan Lainnya yang memiliki potensi yang besar untuk diekspose ke luar. Keunggulan inilah yang menjadikan suatu brand yang Kuat menjadi Kota Wisata Batu (KWB).

Brand Kota Batu yaitu Sebagai Kota Wisata Batu merupakan suatu brand yang suduh cukup dikenal. Oleh karena itu perlu adanya usaha yang memadai untuk membantu menjaga brand yang ada.

b) Brand Identy Melalui Media Internal dan eksternal Humas Pemerintah Kota Batu.

Merupakan kumpulan dari aspek-aspek yang ditujukan untuk menyampaikan maksud dari suatu merek atau brand. Media menjadi suatau cara untuk menyampaikan merek ini kepada publik. Bentuk brand identity yang dilakukan oleh Humas Pemerintah Kota Batu dalam menjaga branding Kota wisata Batu adalah :

\section{Publikasi Kegiatan}

Media-media ini digunakan oleh humas dalam mempublikasikan kegiatan-kegiatan yang ada dan terjadi dalam kaitannya dengan Kota Batu. Kegiatan yang dimaksudkan dalam hal ini berupa kegiatan Wali Kota dan juga kegiatan wakil waliKota sesuai visi misi mereka maupun program Pemerintah dan juga event-event yang diselengarakan. Publikasi yang dilakukan dengan baik dan rutin akan memberikan dampak yang positif terhadap brand Kota ini sendiri. Selain itu Humas Pemerintah Kota Batu juga selalu mengkoordianasikan dengan media media luar untuk membantu untuk mempublikasikan segala kegiatan yang diselenggarakan.

Selain itu juga perlu adanya publisitas yang rutin di media media yang ada, agar publik dapat mengikuti terus perkembanagan yang ada dan manfaat bagi masyarakat luar untuk 
mengetahui keadaan terbaru dari Kota Batu dan menjadi daya tarik sendiri untuk mengunjungi Kota Batu. Publisitas rutin yang dilakukan oleh Humas Pemerintah Kota Batu dalam memberikan informasi mengenai kegiatan yang ada selalu cepat sesuai kegiatan yang dilakukan, karena apabila informasi yang dipublikasikan tidak rutin atau lama menyebarkan informasi yaang ada maka akan dianggap tidak penting lagi untuk diketahui dengan waktuPublisitas dalam media internal seperti media sosial media elektronik biasanya menggunakan foto maupun video yang sudah dikemas secara bagus oleh pihak humas agar dapat disuka oleh seluruh masyarakat maupun publik luar.

\section{Mempromosikan Kota Batu}

Dalam menjaga branding suatu Kota perlu dilakukan juga promosi agar Kota tersebut dapat dikenal baik itu dari segala keunikan dan keistimewaan daerah dpat menyebar luas hingga sampai pada khalayak luas. Humas Pemerintah Kota Batu dalam melakukan promosi wisata yang ada tidaklah lepas dari penggunaan media internal yang dimiliki dan juga media eksternal yang telah menjalin kerjasama. Promosi yang dilakukan dengan menggunakan media-media sendiri seperti media internal dan media eksternal juga memiliki manfaat yang begitu memuaskan.

Penggunaan media internal dan eksternal sendiri oleh Humas Pemerintah Kota batu dalam mempromosikan destinasi wisata baru maupun wisata Lama dianggap lebih efektif. Jenis promosi lewat media internal sendiri lebih kepada memuat berita dan juga foto-foto hingga video tentang keuinkan, ciri khas serta destinasi wisata yang ada di Kota batu.

Penggunaan media dalam menjaga branding Kota Batu sebagai Kota wisata Batu memiliki efek yang sangat besar. Banyak manfaat yang didapatkan melalui promosi maupun publikasi yang ada lewat media. Sebagai keberhasilan dari semuanya itu terbukti pada tahun 2018 dimana meningkatnya jumlah pengunjung Kota Batu. Jumlah kunjungan wisatawan tahun2018 melebihi target dari Pemerintah Kota Batu yaitu 5,2 Juta pengunjung tapi nyatanya mencapai 5,6 juta pengunjung yang terdiri dari pengunjung hotel dan juga daerah tujuan wisata (DTW), Jumlah perhitungan ini seusai peraturan tanpa menghitung pengunjung yang menginap di villa dan home stay. Hal serupa juga dirasakan pada tahun 2017 dimana Pemerintah Kota Batu menargetkan pengunjung 4,1 Juta pengunjung namun yang terealisasi terdapat 4,7 juta pengunjung.

Dengan jumlah wisatawan yang terus meningkat setiap tahun ini membuat salah satu alasan kuat untuk Humas Pemrintahan Kota Batu dalam mempromosikan wisata-wisata Kota Batu baik itu dengan menggunakan media maupun dengan berbagai cara untuk mencapai target yang dinginkan tahun berikut maupun kedepannya oleh Humas Pemerintah Kota Batu

\section{Pelayanan Berbasis Online}

Pelayanan yang baik dalam suatu lembaga Pemerintah merupakan salah satu tolak ukur dari penilain baik buruknya kinerja Pemerintah suatu daerah tersebut. Tumbuh pesatnya perkembangan teknologi saat ini dimana semua masyarakat memiliki ketergantungan yang besar terhadap media, maka Pemerintah Kota Batu tidak tinggal diam untuk menyediakan berbagai jenis pelayan berbasis online. Pelayanan berbasis online yang disiapkan oleh Pemerintah Kota Batu saat ini sudah menjadi salah satu cara yang ampuh dalam memenuhi kebutuhan informasi masyarakat luas. 
Bertambahnya kebutuhan informasi yang dibutuhkan masyarakat saat ini menjadi satu alasan Humas Pemerintah Kota Batu menyediakan berbagai pelayanan berbasis online. Mulai dari informasi yang disampaikan melalui media-media yang ada. Selain itu juga pihak Humas Pemerintah Kota batu tidak membatasi masyarakat Kota Batu dalam mengakses dan mendapatkan informasi yang dianggap penting. Dalam penggunaan media internal terkhususnya dalam pemanfaatan media sosial Humas Pemerintah Kota Batu selain digunakan untuk mempublikasikan segala bentuk kegiatan Kota Batu, mempromosikan tentang Kota batu, namun Humas Pemerintah Kota Batu juga memberikan pelayanan berbasis online dengan cara menerima aspirasi dari setiap masyarakat, keluhan dari masyarakat Kota batu sendiri serta berinteraksi bebas dengan setiap masyarakat yang membutuhkan pelayanan dari Humas Pemerintah Kota Batu.

Namun disisi lain juga mulai gencarnya Pemerintah Kota Batu dalam menyediakan berbagai aplikasi pelayanan informasi yang disediakan baik itu dalam bidang pertanian, teknologi maupun bidang parawisata dll. Aplikasi yang disediakan oleh Pemerintah Kota Batu sangaat beragam mulai dari, Smarty city yang terdapat tida aplikasi yaitu Among Kota, Among Tani dan juga Among Warga selain itu juga ada beberapa aplikasi lainnya yang menyediakan informasi wisata seperti Kota Wisata Batu dan juga Aplikasi Shinning Batu. Aplikasi ini dibuat dengan tujuan untuk memberikan informasi lebih terhadap masalah maupun aspirasi masyarakat Kota Batu dan juga beberapa aplikasi yang dibuat untuk meberkikan informasi tentang destinasi wisata populer maupun destinasi wisata yang baru di Kota Wisata Batu. Selain itu dalam menjalankan tugas dan fungsinya Humas Pemerintah Kota Batu memiliki capaian yang cukup baik pada tahun 2018. Dimana dalam mempublikasikan informasi dan kegiatan serta dalam tugas lainya. Berikut capaian kinerja Humas Pemerintah Kota Batu pada tahun 2018.

\section{c) Brand Personality Melalui Media Internal dan eksternal Humas Pemerintah Kota Batu.}

Brand personality merupakan suatau cara untuk memperbanyak kelebihan dan daya tawar suatu merek. Dalam menjaga brand Kota Batu sebagai Kota Wisata maka hal untuk mengkomunikasika merek itu melalui bantuan dari pihak pihak yang memperkenalkan merek tersebut. Maka dalam hal ini bagaimana keterlibatan masyarakat Kota Batu ikut berpartsisipasi dan terlibat dalam mempromosikan keunggulan dan keunikan dari Kota Batu kepada seluruh masyarakat luar untuk mengetahui dan membuat untuk mengunjungi daerah tersebut. Partisipasi ini dapat berupa kekuatan dari mulut atau biasa di sebut word of mouth yaitu menceritakan melalui mulut ke mulut berdasarkan pengelaman yang di rasakan oleh masyarakat tersebut. Selain itu ada juga beberapa langkah sebagai cara untuk mengkomunikasikan merek tersebut melaui studi banding ke kota batu mulai dari pihak pemerintah daerah luar maupun kampus-kampus luar ke kota batu agar bisa memperkenalakan wisata-wisata Kota Batu yang ada sehingga menjadi salah satu untuk pihak luar mengenal tentang Batu.

Pengelaman-pengelaman baik seperti capaian yang telah di capai oleh Humas Pemerintah Kota Batu juga sebagai suatu penilaiian tersendiri untuk mengukur kualitas Kota Batu sebagai Kota Wisata. Contoh capaian Humas Pemerintah Kota Batu seperti ada 635 berita yang di upload di beberapa media sosial seperti instagram, facebook dan media sosial lainnya. Kemudian ada juga hasil karya berupa video dan juga foto dokumentasi, serta mengadakan kerjasama dengan media luar sebanyak 38 media dan juga meelakukakan jumpa pers dan capaian lainnya. 


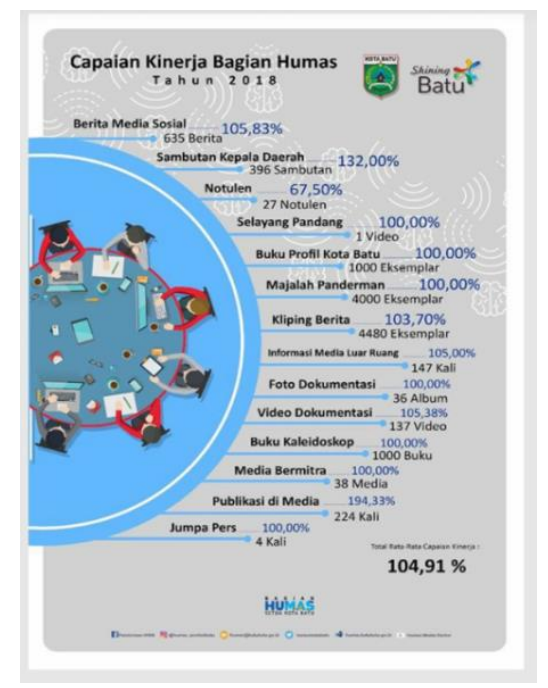

Gambar 4. Capaian Kinerja Humas 2018

Dari semua usaha maupun kerja keras yang telah dilakukan oleh Humas Pemerintah Kota Batu dengan segala bentuk kerjasama dan usaha seluruh pihak Pemerintah Kota Batu, pada tahun 2019 ini Kota Batu mendapatlan banyak penghargaan. Penghargaan yang didapat berkat segala usaha semua pihak yang telah mendukung Kota Batu dengan berbagai cara. Penghargaan yang didapatkan Kota Batu pada Tahun 2019 seperti Sertifikat Adipura, Sakip Awards 2018, Destinasi Wisata Unggulan, Penghargaan Best WaliKota dan Penghargaan Best Inovation On Medium \& Small Govermance dan juga beberap penghargaan lainya.

\section{Kesimpulan}

Dalam menjaga branding yang ada Humas Pemerintah Kota Batu menggunakan mediamedia yang ada seperti media internal dan eksternalnya. Terdapat media internal Hubungan Masyarakat Kota Batu seperti majalah Panderman dan juga buletin Kaleodskop dan De Kleine Sitzerland dan Televisi yang digunakan untuk menyebarkan informasi dalam lingkup Instansi pemerintahan di Among tani. Lalu media eksternal terdiri dari media online seperti website Humas Pemerintah Kota Batu kemudian Atv dan juga media sosial seperti Instagram, Facebook, youtube, dan juga twitter.

Strategi branding yang dilakukan oleh Hubungan Masyarakat Pemerintah Kota Batu dengan menggunakan media baik media internal dan media eksternal terdapat tiga point yaitu: Brand positioning, dimana Humas pemerintah Kota Batu menggunakan media internal dan eksternal untuk mempromosikan dan mengidentifikasikan keunggulan dari kota batu sebagai Kota Wisata Batu. Brand Identy, yaitu dengan menggunakan media internal dan media eksternal yang untuk menyampaika maksud dari brand Kota batu sendiri. Brand personality, dimana sebagai suatu cara mengkomunikaikan merek yang ada melalui pengelaman orang yang memperkenalkannya.

\section{Daftar Pustaka}

Christin, Maylanny dan Fauzan, Siti Faridani. 2015. City Branding Kota Bandung melalui Bus Bandros. Jurnal Komunikator, Vol. 7 No. 2, hlm. 87-92.

Fajrini, Nurkhalila., Bakti, Iriana, \& Novianti, Evi. 2018. City Branding Sawahlunto Kota Wisata Tambang Yang Berbudaya Melalui Event Sawahlunto International Songket Carnival (Sisca) 2016. PRofesi Humas: Jurnal Ilmiah Ilmu Hubungan Masyarakat, Volume 2, No. 2, hlm. 169-185.

Hermawan. 2012. Komunikasi Pemasaran. Jakarta: Erlangga. 
JISIP: Jurnal Ilmu Sosial dan Ilmu Politik

ISSN. 2442-6962

Vol. 9. No. 2 (2020)

Jannah, Bidriatul., Arifin, Zainul., \& Kusumawati, Andriani. 2014. Pengaruh City Branding dan City Image Terhadap Keputusan Berkunjung Wisatawan ke Banyuwangi. Jurnal Administrasi Bisnis (JAB), Vol. 17 No. 1, hlm. 1-7.

Jefkins, Frank. 2004. Public relations, edisi kelima. Jakarta: Erlanggga.

Lestari, Retno Budi. 2016. Membangun Citra Sebuah Kota Dalam Persaingan Global Melalui City Branding. Forum Bisnis Dan Kewirausahaan: Jurnal Ilmiah STIE MDP, Vol. 5 No. 2, hlm. 68-79.

Mursyid, Moh. 2016. Personal Branding pustakawan. Yogyakarta: Lembaga Ladang Kata.

Nasrullah, Rulli. 2015. Media Sosial Perspektif Komunikasi, Budaya dan Sosioteknologi. Bandung: Simbiosa Rekatama Media.

Oktaviani, Femi. 2018. Strategi Branding Public Relations "Jendela Alam" dalam Mengembangkan Produk Agrowisata. Jurnal MediaTor, Vol 11 (2), hlm. 203-213.

Ruslan, Rosady. 2014. Manajemen Public Relations dan Media Komunikasi Konsep dan Aplikasinya (Edisi Revisi. Jakarta: Raja Grafindo Persada.

Sugiyono. 2014. Metode Penelitian Kuantitatif dan Kualitatif. Bandung: Alfabeta.

Widjaja, H. A. W. 2008. Komunikasi dan Hubungan Masyarakat. Jakarta: Bumi Aksara.

Zuriah. 2007. Metode Penelitian Sosial \& Pendidikan. Jakarta: PT Bumi Aksara. 